\title{
Foraging black-browed albatrosses target waters overlaying moraine banks - a consequence of upward benthic-pelagic coupling?
}

\author{
EWAN D. WAKEFIELD ${ }^{\mathbf{1}, \mathbf{2}}$, RICHARD A. PHILLIPS ${ }^{\mathbf{1}}$ and MARK BELCHIER ${ }^{\mathbf{1}}$ \\ ${ }^{I}$ British Antarctic Survey, NERC, High Cross, Madingley Road, Cambridge CB3 OET, UK \\ ${ }^{2}$ current address: Institute of Integrative \& Comparative Biology, University of Leeds, Manton Building, Leeds LS2 9JT, UK \\ e.d.wakefield@leeds.ac.uk
}

\begin{abstract}
Wide-ranging, surface-feeding pelagic seabirds are the most numerous functional group of birds in the Southern Ocean. The mesoscale habitat use of these birds is increasingly being quantified by relating their movements to remotely sensed, near surface properties of the ocean. However, prey availability at the sea surface may also be determined by habitat characteristics not measurable from space. For instance, benthic-pelagic coupling, which occurs when seabed processes affect productivity in the epipelagic zone, can link benthic habitat type to availability of surface prey. We combined acoustically derived maps of the substrate of the South Georgia shelf with GPS tracking to quantify the sub-mesoscale habitat use of breeding black-browed albatrosses. We show that albatrosses preferentially used waters overlaying glacial moraine banks near the shelf edge and that this was unrelated to the presence of trawlers targeting mackerel icefish, which are also associated with these features. Stomach temperature profiles suggest that albatrosses primarily caught krill and fish over the banks. We hypothesize that black-browed albatrosses target waters overlaying moraine banks due to upward benthic-pelagic coupling, mediated by an increase in abundance of zooplankton such as Antarctic krill. Our findings suggest that the potential effects of such processes on pelagic seabird distribution warrant wider investigation.
\end{abstract}

Received 14 November 2011, accepted 22 December 2011, first published online 6 March 2012

Key words: Antarctic krill, individual movement, seabird bycatch, stomach temperature loggers, submesoscale habitat use, Thalassarche melanophris

\section{Introduction}

A principal aim of ecology is to understand the links between species and habitats. This is hard to achieve, however, when organisms or the regions they inhabit are remote or otherwise difficult to observe. One group of such animals that are particularly abundant in the Southern Ocean are the surface feeding, pelagic seabirds. Because these birds routinely range hundreds to thousands of kilometres from their breeding colonies in search of food it has become the norm to study their foraging ecology using remote sensing technology. Typically the approach is as follows: miniature devices attached to the birds record their movements and behaviour, while satellites simultaneously measure the dynamic biological and physical properties of the wide areas of ocean in which they forage (e.g. Wakefield et al. 2011). As such, the habitats of pelagic seabirds (and many other wide-ranging higher marine predators) are frequently described in terms of superficial properties of the ocean measured using satellite remote sensing. These include sea surface temperature, sea surface height, chlorophyll $a$ and so on, as well as their derivatives, including primary productivity, mesoscale turbulence etc. (reviewed by Wakefield et al. 2009).

Despite the insights gained using this approach, the availability of food at or near the surface of the ocean is not solely dependent on processes readily measurable from space. In particular, upward benthic-pelagic coupling can have a major influence on the productivity of shelf sea ecosystems (Smith et al. 2006). It follows that depth and substrate type could also influence the distribution of surface-feeding or shallow diving seabirds even if they cannot access the seabed itself. Though it has long been recognized that bathymetry can play an important role in defining pelagic seabird habitat suitability, variability in substrate type and small-scale bathymetry have rarely been explicitly considered in analyses of habitat preference of surface-feeding, pelagic seabirds. This is despite the fact that mid-water and epipelagic fisheries for the same species preyed upon by seabirds often target waters overlaying particular substrate types or bathymetric features (Greenstreet et al. 1999). In Antarctic waters, examples of upward benthicpelagic coupling caused by such features include currents interacting with complex topography, resulting in nutrient transport from the seabed into the water column (Sedwick et al. 2000, Atkinson et al. 2001), and euphausiids feeding on accumulations of biogenic detritus on the seabed and then migrating to the surface, where they are consumed by higher predators (Gutt \& Siegel 1994, Smith et al. 2006). It is possible therefore, that seabed characteristics, such as substrate type, may in part determine habitat quality for surface-feeding 
pelagic seabirds. In turn, this implies that substrate may be a useful predictor of these species' distribution.

The black-browed albatross Thalassarche melanophris (Temminck, 1828) is one of the world's largest and most wide-ranging pelagic seabirds. It breeds on sub-Antarctic islands, with population centres in the Falkland Islands (c. 414000 pairs), southern Chile (c. 123000 pairs) and South Georgia (c. 74000 pairs) (Wakefield et al. 2011). During foraging trips, breeding black-browed albatrosses show a marked preference for shelf and shelf slope habitats (Cherel et al. 2000, Wakefield et al. 2011), where they principally catch fish, cephalopods and crustaceans (Reid et al. 1996, Cherel \& Klages 1998, Cherel et al. 2000). During non-breeding periods birds forage in temperate neritic, and in the case of some populations, oceanic waters but little is known of their diet during these stages (Phillips et al. 2005). Their limited diving capabilities mean that they capture prey either at or within $5 \mathrm{~m}$ of the surface (Prince et al. 1994). Despite this constraint, they frequently consume benthic or semi-pelagic organisms, such as nototheniid and channichthyid icefish (Cherel \& Klages 1998, Cherel et al. 2000). In some instances, black-browed albatrosses obtain such prey by scavenging discards from fishing vessels, which in some areas can make up a significant proportion of their diet (Reid et al. 1996). However, these prey may also be consumed by birds in the absence of fishing activity (Cherel et al. 2000). Therefore, although the mechanisms by which benthic prey become accessible at the surface are unclear, it is possible that black-browed albatross distribution may be influenced by that of particular benthic habitats.

The need to understand black-browed albatross habitat use, especially where this overlaps with commercial fishing grounds, has become more than academic over recent years. This is because incidental bycatch by both longline and trawl fisheries is leading the species into a potentially terminal decline, such that since 2002 it has been formally recognized as endangered (www.iucnredlist.org, accessed May 2011). During the breeding season, the foraging areas used by birds from the South Georgia population, on which our study focuses, are also used by mid-water trawlers targeting Antarctic krill Euphausia superba (Dana, 1852) and mackerel icefish Champsocephalus gunnari (Lönnberg, 1905) (Kock 2001). The potential for overlap between these trawlers and black-browed albatrosses is heightened because krill are a major component of the diet both of this species and mackerel icefish (Kock et al. 1994, Cherel \& Klages 1998).

Until recently, little was known about the benthic habitats surrounding South Georgia. However, analysis of high-resolution multibeam swath bathymetry data collected over the shelf has now revealed a series of banks and ridges, rising from a few metres to $>75 \mathrm{~m}$ above the surrounding seabed (Graham et al. 2008, Fretwell et al. 2009). These features, which are concentrated along the shelf edge, especially to the north and west of the islands, are thought to comprise terminal moraines formed during the last glacial maximum at the seaward margins of once extensive ice sheets (Graham et al. 2008). As such, they probably form a substrate of unconsolidated cobbles and boulders, that support a richer fauna than surrounding bedrock habitats (Barnes 2008).

Here, we use seabed substrate data as a habitat proxy, and highly accurate GPS tracking to test the hypothesis that black-browed albatrosses forage in a non-random manner with respect to benthic habitats on the South Georgia shelf. We then use auxiliary logger data to examine variability in prey capture and activity with respect to habitat type. In addition, we investigate potentially confounding interactions between tracked birds and fishing vessels operating within the study area. We discuss our findings in the context of possible mechanisms of upward benthic-pelagic coupling and their implications for understanding pelagic seabirdhabitat relationships and seabird-fishery conflicts in the Southern Ocean and beyond.

\section{Materials and methods}

\section{Context, definitions and instrumentation}

Fieldwork was carried out at Bird Island, South Georgia $\left(54^{\circ} 00^{\prime} \mathrm{S}, 38^{\circ} 03^{\prime} \mathrm{W}\right)$ between January and March 2008. During January, adult black-browed albatrosses at South Georgia are engaged in rearing small, recently hatched chicks. In this period (hereafter 'brood-guard') parents alternate between foraging at-sea and remaining at the nest to brood and feed their chicks (i.e. one or other parent always attends the chick). Brood-guard foraging trips are typically short (mean duration from Bird Island c. 50 hours, mean maximum distance from the colony c. $300 \mathrm{~km}$ ) and mainly to neritic or shelf break waters surrounding South Georgia but they may also be directed to other local oceanic waters (Phillips et al. 2004). From the end of January onwards chicks are large enough to be left unattended and both parents forage at the same time to meet the energetic demands of both themselves and their offspring. During this period (hereafter 'post-brood') they continue to make trips to local waters but also travel to more distant patches of neritic, shelf break and oceanic habitat (mean trip duration $c .75$ hours, mean maximum distance from the colony c. $470 \mathrm{~km}$ ) (Phillips et al. 2004).

During fieldwork, we deployed GPS loggers programmed to record positions every 5,15 or 30 minutes on a total of 49 black-browed albatrosses. These were either Mini-GPSlogs ( $29 \mathrm{~g}$, 'earth \& OCEAN Technologies', Kiel, Germany), GPS-DLs (38 g, New Behaviour AG, Zurich, Switzerland) or GPS-RF tags ( $36 \mathrm{~g}$, e-obs GmbH, Munich, Germany). Ten birds were also equipped with a Stomach Temperature Archival Unit (STAU) (MiniTemp, 33-37g, 'earth \& OCEAN Technologies', Kiel, Germany) set to log the temperature in 
the bird's proventriculus at intervals of 1,2 or 20 seconds. These data were later analysed to determine the timing of prey ingestion and the approximate mass of prey items (see Catry et al. (2004) for details of deployment and recovery techniques). All birds also carried a Mk7 combined light and immersion logger (4g, British Antarctic Survey, Cambridge, UK) and during post-brood, to facilitate recapture, a VHF transmitter $(17 \mathrm{~g}$, Sirtrack, Havelock North, New Zealand). These devices were attached to plastic bands placed around the tarsus of the birds' legs. The Mk7 records the time of transition ( $3 \mathrm{sec}$ resolution) between wet/dry states providing the new state lasts more than $6 \mathrm{sec}$. A state change of less than $6 \mathrm{sec}$ is ignored. Of the birds not equipped with a STAU, seven were equipped with a second small GPS logger set to record locations every $1-5$ seconds ( 8 or $23 \mathrm{~g}$, Technosmart, Rome, Italy, data not presented here). The mass of birds was measured prior to instrument attachment. Median total mass of instruments and attachment material was $68 \mathrm{~g}$ or $2 \%$ of body mass (range 46-105 g, 1-3\%). To establish whether tracking had any deleterious effects on breeding performance, nests of tracked birds were matched with a nearby control, and both nests visited regularly until the end of the breeding season to establish whether the chicks fledged.

Calibration of the STAUs, as well as feeding trails (data not presented here), was performed following Catry et al. (2004). Briefly, three non-breeding adult black-browed albatrosses were captured in the colony and taken to a purpose built wooden holding pen (floor area $25 \mathrm{~m}^{2}$, height $2 \mathrm{~m}$ ). While birds were in the holding pen they did not attempt to escape or fly but spent most of their time sitting on the ground. After being left for $3-4 \mathrm{~h}$ to become accustomed to their surroundings the birds were induced to swallow a STAU. Following a period of either $2.5 \mathrm{~h}$ (one bird) or $12 \mathrm{~h}$ (two birds) they were then fed two meals of mackerel icefish, two meals of the squid Illex argentinus (Castellanos, 1960), three meals of Antarctic krill Euphausia superba (Dana, 1850) and one meal of the mantle tissue of the Cnidarian Periphylla periphylla (Péron \& Lesueur, 1810). Meal masses were between 1.3 and $105.8 \mathrm{~g}$. In addition birds ingested $100 \mathrm{ml}$ of seawater. This and the meals were all at a known temperature of between -0.3 and $3.4^{\circ} \mathrm{C}$. An interval of at least an hour was left between meals in order to allow the temperature of the proventriculus, meal and STAU to equilibrate. The birds did not show any signs of undue stress during these procedures, did not attempt to regurgitate any meals and settled down immediately after being fed. At the end of the feeding trials STAUs were recovered and the birds were released back into the colony. The time elapsed between capture and release for the three birds was 28,40 and $41 \mathrm{~h}$ respectively.

\section{Fisheries data}

The waters around South Georgia fall within the Fisheries Conservation and Management Zone (FCMZ) of the South
Georgia and South Sandwich Islands and are subject to conservation measures set by the Commission for the Conservation of Antarctic Marine Living Resources (CCAMLR). The Government of South Georgia and the South Sandwich Islands issues licences to a limited number of fishing boats to operate in the FCMZ each year and sets catch limits for different target species. During the study period (January-March) longlining is prohibited in order to mitigate seabird bycatch but a limited amount of mid-water trawling for mackerel icefish and Antarctic krill is permitted. The locations of all sets and hauls made by boats engaged in these fisheries are reported to CCAMLR, along with catch totals. We obtained these data from CCAMLR for the period 2000-08. Illegal fishing is effectively prevented in South Georgia waters by regular fisheries patrols and surveillance by licensed fishing vessels so these data are thought to summarize all fishing activity in the area.

\section{Habitat data}

Hereafter we refer to shelf (or neritic) waters as those shallower then $500 \mathrm{~m}$, which is the approximate depth of the South Georgia shelf break. We refer to upper shelf slope waters as those $500-1000 \mathrm{~m}$ deep and oceanic waters as those $>1000 \mathrm{~m}$ deep. We use the term moraine bank to refer to those features identified as such on the South Georgia shelf by Graham et al. (2008). We downloaded high-resolution ( $150 \mathrm{~m}$ cell size) bathymetric data compiled
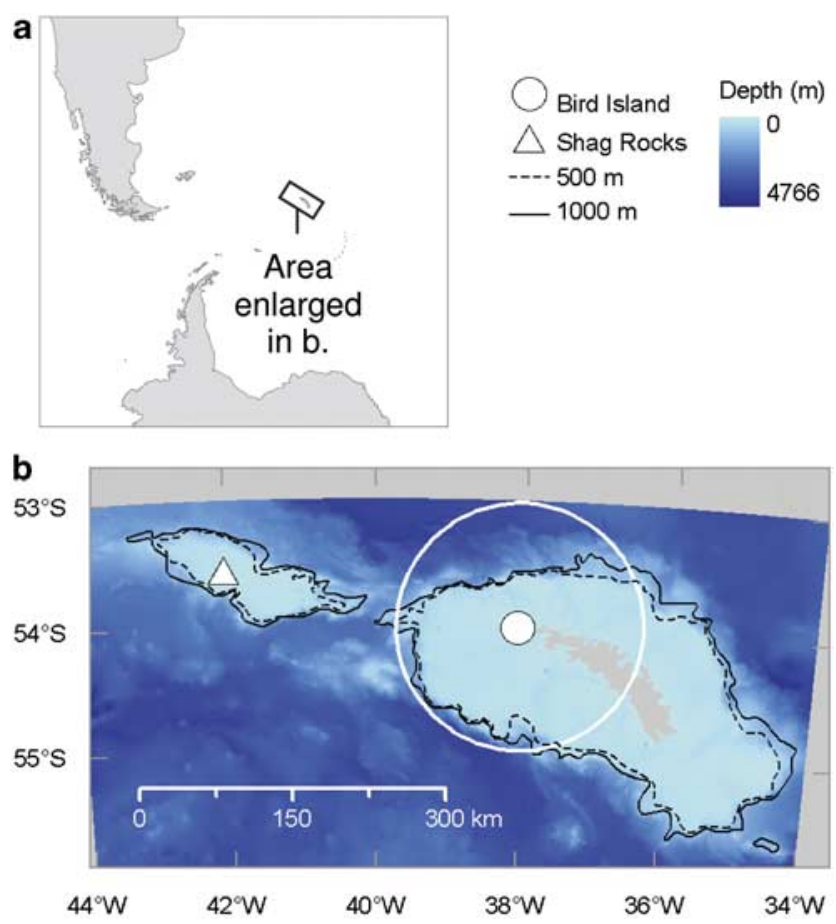

Fig. 1. Location of the study area and places mentioned in the text. High-resolution bathymetric data were not available for areas shaded grey in $b$. 
by the British Antarctic Survey (BAS, Cambridge, UK) from single and multi-beam swath bathymetry (Fretwell et al. 2009) from http://www.antarctica.ac.uk/bas_research/ data/online_resources/sgbd/ (accessed November 2010). We also obtained an ESRI shape file defining the extent of benthic moraine banks on the South Georgia shelf identified by Graham et al. (2008) from BAS. This study did not include the shallow waters around Shag Rocks, $270 \mathrm{~km}$ to the WNW of Bird Island. Therefore, we had no information on the presence or absence of submarine moraine features in this area or indeed in shelf waters elsewhere that may be utilized by black-browed albatrosses breeding at Bird Island. For this reason we confined our analysis of albatross movements, habitat use and prey ingestion to waters within $120 \mathrm{~km}$ of Bird Island (Fig. 1, hereafter the study area). The shape and extent of this area was defined to exclude the Shag Rocks shelf, omit areas of the South Georgia shelf that have poor bathymetric data coverage (Graham et al. 2008, fig. 2) and reflect the fact that breeding albatrosses are central place foragers (Wakefield et al. 2009). We also excluded waters within $3 \mathrm{~km}$ of Bird Island from the study area because albatrosses tended to spend time on the surface of the sea close to the colony. The function of this behaviour is unclear but such rafting by seabirds is not thought to be associated with foraging (Waugh et al. 2000).

\section{Analysis}

We reduced all GPS tracking data to the same temporal resolution (one location every 30 minutes), if necessary, by retaining only every second or every sixth location. In order to test whether black-browed albatrosses used waters overlaying moraine banks more frequently than they would by chance we first compared their use of moraine bank areas to their availability (Johnson 1980). Adopting a case-control design (Aarts et al. 2008, Wakefield et al. 2011), we regarded GPS points as indicative of a bird's presence at a location. We then generated pseudo-absence locations quasi-randomly as controls for each presence location, at a rate inversely proportional to distance from Bird Island. This resulted in a null model, in which the probability of an albatross using a location is inversely proportional to its distance from the colony (i.e. locations close to the colony are more easily accessible and therefore more probably used by chance than those further away). For each presence location a total of four pseudo-absence locations were generated, this number being chosen to give a reasonable representation of available habitat and to stay within computational limits (Aarts et al. 2008). We then modelled the presence/absence of birds as a function of substrate type and depth. The latter covariate was included because moraine banks on the South Georgia shelf tend to occur just landward of the shelf break (Graham et al. 2008).
It is possible that a preference for this feature, like that expressed by black-browed albatrosses foraging from Kerguelen (Cherel et al. 2000, Pinaud \& Weimerskirch 2007), could give the spurious impression that moraine banks were preferred simply because they are adjacent to the shelf break. Models were structured as mixed-effects generalized additive models with a binomial error structure, fitted using the package gamm4 run in the statistical software R. Individual bird was specified as a random effect, and substrate and depth as fixed-effects. Substrate was classified in two ways: firstly, substrate I was defined according to whether locations overlay a moraine bank or not. Secondly, to account for potential local advection of prey associated with the presence of the banks, substrate II was defined according to whether locations lay within a $2 \mathrm{~km}$ buffer surrounding the moraine banks.

Four models were considered: models Ia and $\mathrm{Ib}$ were fitted to locations of all birds within the study area. We then assumed that birds recorded on the same day as and within $33 \mathrm{~km}$ of the locations of icefish hauls, potentially interacted with fishing vessels (the distance of $33 \mathrm{~km}$ is based on a maximum trawl time during 2008 of $3 \mathrm{~h}$ and the assumption that working trawlers travelled at $\leq 5$ knots). We therefore fitted models IIa and IIb to locations from birds during periods when they did not have the potential for interaction with a working trawler.

In order to examine activity patterns with respect to habitat and daylight, bird activity at each tracking location was determined using immersion logger data. The proportion of locations when the loggers were wet was calculated for each bird within each habitat type and for periods of darkness and light. This index was used as an estimate of the proportion of time spent on the water in each category within these habitats. Locations were classified as dark if the sun was $<6^{\circ}$ below the horizon (i.e. between the end of evening, and the start of morning civil twilight) or light otherwise. Times of civil twilight were calculated using standard astronomical algorithms.

Analysis of STAU data was carried out using methods described by Wilson et al. (1995). Following prey ingestion, proventriculus temperature typically falls precipitously and then rises exponentially (a precipitous drop, exponential rise or PDER event). The timing of each PDER event, and the integral (INT) above the curve of temperature vs time for that event were estimated using the program MultiTrace Temp (Jensen Software Systems, Laboe, Germany). The mass $M$ of food ingested was estimated according to:

$$
M=\mathrm{INT} /\left[m \times S H C_{\mathrm{f}} \times\left(T_{\mathrm{a}}-T_{\mathrm{f}}\right)\right]
$$

where $S H C_{\mathrm{f}}$ is the specific heat capacity of the prey item, which was assumed to be $4.0 \mathrm{~J} \mathrm{~g}^{-1}{ }^{\circ} \mathrm{C}^{-1}$ (Putz et al. 1998); $T_{\mathrm{a}}$ is the temperature to which the food must be heated; and $T_{\mathrm{f}}$ is the temperature of the food. The constant $m$ is defined as:

$$
m=\mathrm{INT} / E
$$




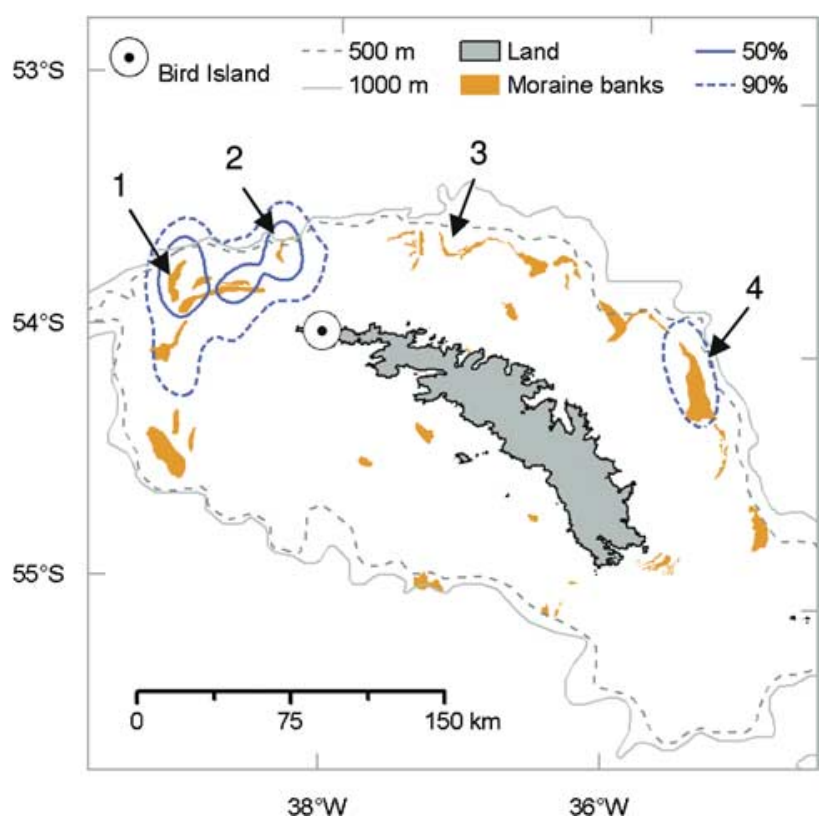

Fig. 2. Benthic moraine banks on the South Georgia shelf identified by Graham et al. (2008), overlaid with the distribution of icefish trawling activity (contours containing 50 and $90 \%$ kernel density of all haul locations reported between 2000 and 2008). Numbers indicate moraine banks or groups of banks discussed in the text.

where $E$ is the energy required to heat the food to the equilibrium temperature of the proventriculus, which can be estimated by:

$$
E=S H C_{\mathrm{f}} \times M_{\mathrm{f}} \times\left(T_{\mathrm{a}}-T_{\mathrm{f}}\right) .
$$

We estimated $m$ by evaluating the gradient of INT vs $E$ for prey items of known mass ingested by the three blackbrowed albatrosses during the feeding trials (Wilson et al. 1995, Catry et al. 2004). For free-ranging birds, $T_{\mathrm{f}}$ was assumed to be the equal to the sea surface temperature (SST) at the location where prey items were captured. These locations were estimated by linear interpolation between the GPS locations preceding and following PDER events. $T_{\mathrm{f}}$ was then determined from weekly mean Optimally Interpolated SST data, obtained on a $1^{\circ}$ grid from the National Oceanic and Atmospheric Administration, Boulder, CO (http:// www.esrl.noaa.gov/psd/data/gridded/data.noaa.oisst.v2.html, accessed November 2010). Where $n$ multiple-PDER events overlapped one another, the total meal mass $M$ was calculated and then the mass of individual prey items estimated as $M / n$.

\section{Results}

\section{Fishing activity}

Between 2000 and 2008 trawlers targeting icefish concentrated their activity over moraine banks landward of the South Georgia shelf break. Two distinct areas were targeted: the
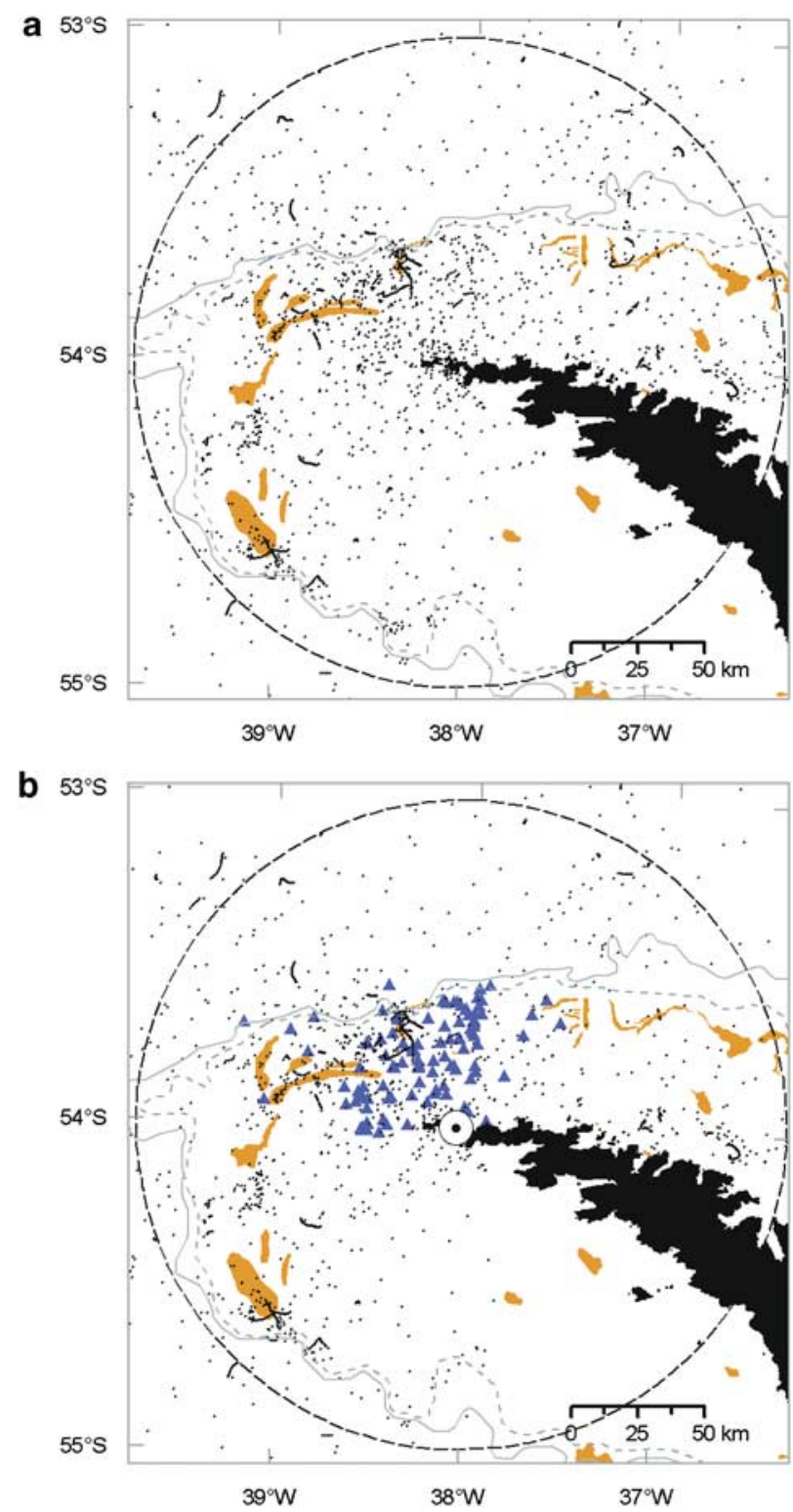

Fig. 3. Half hourly locations (black dots) of black-browed albatrosses GPS-tracked from Bird Island, South Georgia within the study area (dashed line). a. Locations from all birds tracked $(n=49)$, and $\mathbf{b}$. locations only from birds that remained at least $33 \mathrm{~km}$ from icefish hauls sites (blue triangles indicate locations where the other birds came within $33 \mathrm{~km}$ of an icefish haul, remaining symbols are as in Fig. 2).

first coinciding with a concentration of banks to the northwest of South Georgia (banks 1 and 2, Fig. 2) and the second a large bank to the north-east of the island (bank 4). During the study period (January-March 2008) four trawlers operated on the South Georgia shelf. Fishing activity was not continuous during this time but was largely carried out by two boats in two non-overlapping bouts. The first boat made 40 hauls between 19 January and 2 February. These were predominantly in an area $35 \mathrm{~km}$ 
Table I. Fixed effects in mixed-effects Generalized Additive Models of black-browed albatross habitat use in waters between 3 and $120 \mathrm{~km}$ from Bird Island, South Georgia. Parameters are expressed in logits (i.e. on the scale of the Generalised Additive Model canonical link function for the binomial distribution). Logits may be transformed to the scale of the response variable according to the formula $\operatorname{logit}{ }^{-1}(\alpha)=\exp (\alpha) / 1+\exp (\alpha)$, where $\alpha$ in the parameter value. $\mathrm{SE}=$ standard error, $\mathrm{z}=$ the Wald statistic.

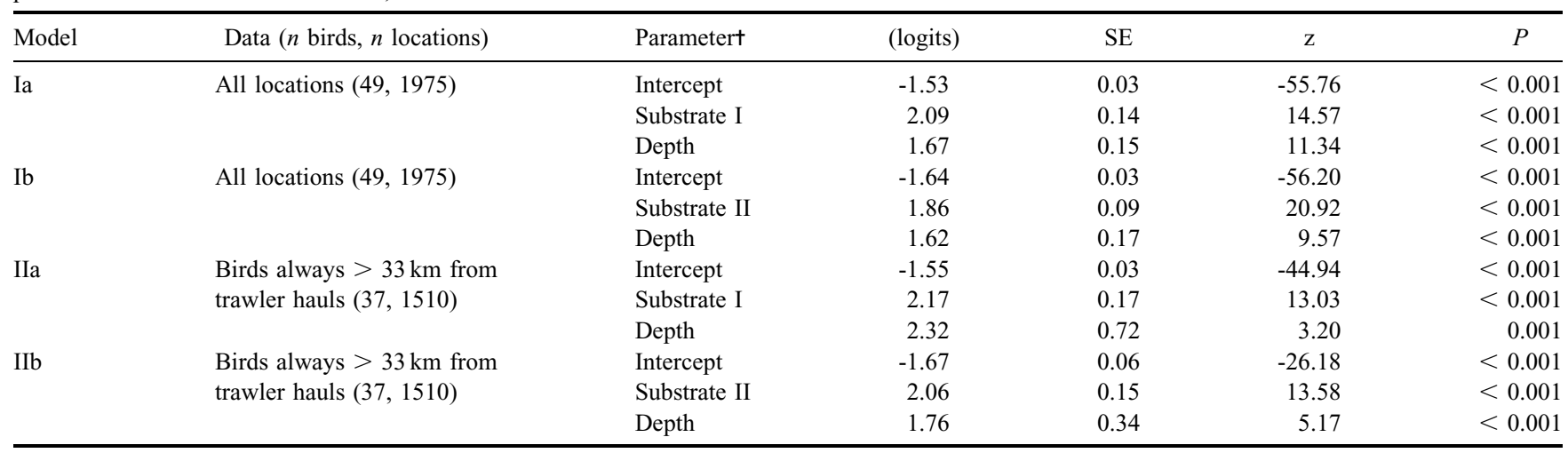

†Substrate I defined as 1 if locations overlay a moraine bank or 0 otherwise. Substrate II defined as 1 if locations overlay a moraine bank plus a $2 \mathrm{~km}$ buffer or 0 otherwise.

north of Bird Island, where no moraine banks have been identified. However, a small number of hauls were also made in the study area over bank 1, north-west of the island. Two further boats made three additional hauls during this period. After a pause of two weeks, fishing resumed on 16 February and continued until 1 March. During this time, one boat carried out 31 hauls, which were predominantly over a single moraine bank in the study area $40 \mathrm{~km}$ to the WNW of Bird Island (bank 2). A total of $750 \mathrm{t}$ of mackerel icefish was caught during the study period (CCAMLR 2009). No fishing for krill on the South Georgia shelf was reported in 2008.

\section{Albatross habitat use and behaviour}

A total of 49 foraging trips made by breeding adult blackbrowed albatrosses were tracked using GPS loggers. The percentage of chicks successfully fledged by the 49 pairs that included a tracked bird (65\%) did not differ significantly from that of the matched controls $\left(61 \%, \chi^{2}=0.001, n=98\right.$ pairs, $P=0.971)$. Furthermore, the fledging success of chicks of tracked birds was not significantly related to instrument mass (generalized linear model with quasibinomial errors, $\left.F_{1,47}=1.502, P=0.224\right)$. Foraging trips lasted between 0.6 and 18.7 days (median 3.1 days). The maximum distances from the colony reached by birds ranged from $96-2191 \mathrm{~km}$ (median $433 \mathrm{~km}$ ). Although most trips were to the Shag Rocks or more distant areas, 13 were confined entirely to the South Georgia shelf. During 11 of the latter, $\geq 75 \%$ of the birds' time was spent within the study area. Some birds on longer trips also spent an appreciable amount of time on the South Georgia shelf, rather than commuting rapidly through the area.

Moraine banks in the study area had a gently sloping relief and the maximum gradient of each of the banks had a median value of $6^{\circ}$ (range $1-15^{\circ}$ ). Moraine banks were located in waters with a mean depth of $261 \mathrm{~m}$ (range $143-320 \mathrm{~m}$ ) and on average rose to a maximum of $54 \mathrm{~m}$ above the surrounding seabed (range 13-161 m). Within the study area, black-browed albatross spatial usage was highest around the colony and towards the shelf break. A total of 29 birds visited waters overlaying moraine banks and 39 birds visited waters overlaying either the banks or the $2 \mathrm{~km}$ buffer zone. Banks 1, 2, 3 and 5 were used most frequently (Fig. 3) but bank 4 and other banks outside the study area were also visited by one or two birds each. Overall, $7 \%$ of albatross locations within the study area overlaid moraine banks (ranging from $0-40 \%$ for individual birds) and $17 \%$ overlaid or were within $2 \mathrm{~km}$ of the edges of moraine

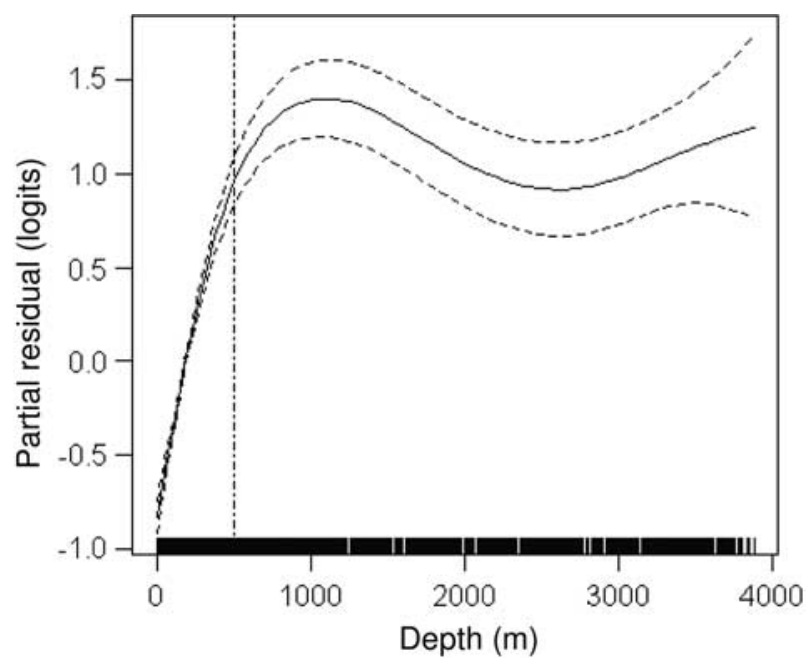

Fig. 4. Variation in habitat use with depth by black-browed albatrosses within $120 \mathrm{~km}$ of Bird Island, South Georgia, predicted by a mixed-effects Generalized Additive Model (model Ia). The y-axis shows the partial residual once the effects of substrate type have been removed and is proportional to habitat use vs availability. Dashed lines indicate estimated $95 \%$ confidence intervals. The approximate depth of the South Georgia shelf break is indicated by the vertical dot-dashed line. 


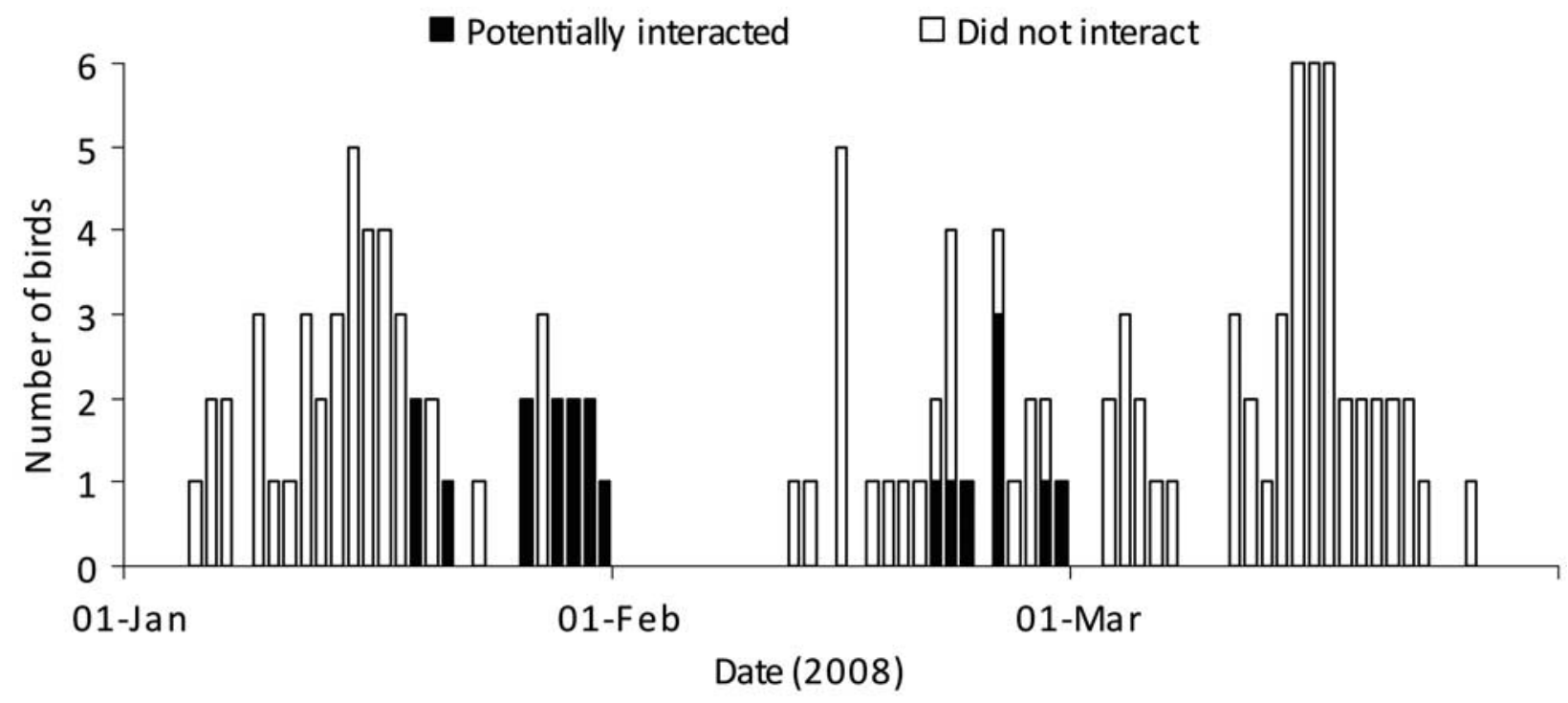

Fig. 5. Number of GPS-tracked black-browed albatrosses within the study area during each day of the study and the number of those birds that could potentially have interacted with trawlers. Potential interaction was deemed to be possible if a tracked bird came within $33 \mathrm{~km}$ of the location of a haul on the day in question.

banks (range for individual birds 0-53\%). In comparison, the banks themselves comprised only $2 \%$ of the seabed in the study area (or $7 \%$ when the $2 \mathrm{~km}$ buffer was included). Only $1 \%$ of pseudo-absence locations (see Materials and methods) were over the banks, and an additional $2 \%$ over the $2 \mathrm{~km}$ buffer. Models Ia and Ib, fitted to all tracking data from the study area (49 birds) indicated that moraine banks and moraine banks plus the $2 \mathrm{~km}$ buffer were used significantly more frequently than would be expected by chance (Table I). In addition, locations close to the shelf break were used more frequently than expected (Fig. 4).

Within the study area, during daylight, birds spent little time on the water (median 14\%, 1st and 3rd quartiles $8 \%$ and $29 \%$, range $0-69 \%$ ). Conversely, during darkness they spent the majority of their time on the water (median $81 \%$, 1 st and 3 rd quartiles $58 \%$ and $92 \%$, range $0-100 \%$ ). The activity of birds while in the vicinity of the moraine banks followed this overall pattern and did not differ significantly from their behaviour elsewhere (paired $t$-test, percentage of locations within the $2 \mathrm{~km}$ buffer wet vs percentage of locations outside the $2 \mathrm{~km}$ buffer wet, $t_{38}=-0.586$, $P=0.561)$.

A total of 12 tracked birds came within $33 \mathrm{~km}$ of icefish trawlers engaged in hauling. However, across the study period and site as a whole, potential fishery-albatross interactions were rather limited. They occurred almost exclusively in the area of shelf to the north and west of Bird Island, some in the vicinity of banks 1 and 2 (Fig. 3b), during two distinct periods: firstly from 19-31 January and secondly from 21-28 February (Fig. 5). Considering only the 37 birds that did not at any point come within $33 \mathrm{~km}$ of an icefish haul, $8 \%$ of locations within the study area overlay moraine banks (range for individual birds $0-40 \%$ ) and $19 \%$ overlay or were within the $2 \mathrm{~km}$ buffer (individual range 0-53\%). Models IIa and IIb indicate that the rate of use of moraine bank habitats by birds which did not interact with fishing boats was higher than expected by chance (Table I).

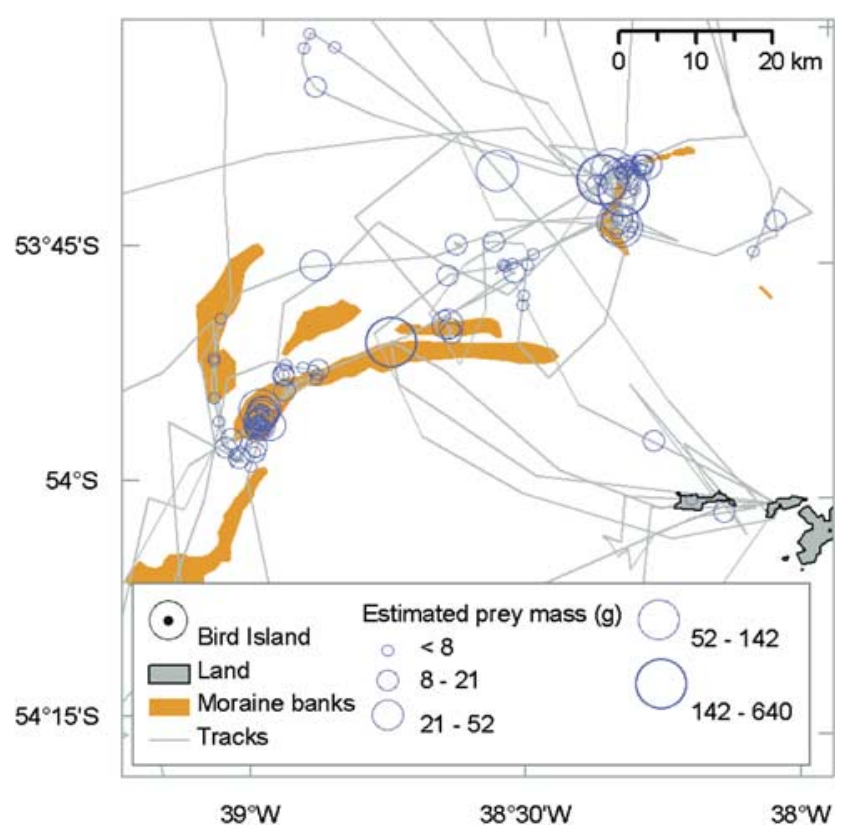

Fig. 6. Detail of single foraging trips made by two blackbrowed albatrosses (birds \#22 and \#27) from Bird Island, South Georgia in relation to moraine banks showing the estimated location and mass of prey items taken in foraging events. 


\section{Prey capture}

The value of the constant $m$ ( $\pm 95 \%$ confidence interval (CI)), estimated following feeding trials with three non-breeding adult black-browed albatrosses, was $0.0083 \pm 0.0009^{\circ} \mathrm{C} \mathrm{s} \mathrm{J}^{-1}$ (linear regression, $r^{2}=0.95, F_{1,19}=377.8, P<0.001$ ). Single meal masses estimated for captive birds using this value had a median prediction error of $\pm 23 \%$ of their true value (lower and upper quartiles 11 and $45 \%, n=20$ ). STAU data were successfully obtained from seven free-ranging birds (the other two birds regurgitated their STAU at sea and one logger malfunctioned). Four of these birds commuted over the South Georgia shelf to forage in more distant waters (data not shown here), ingesting from three to seven prey items on their way through the study area. Of the remaining three birds, two (\#22 and \#27) made complex looping trips, foraging primarily over banks 1 and 2 to the west and north-west of Bird Island, returning to the vicinity of the colony on a number of occasions before finally returning to the colony itself (Fig. 6). Bird \#22 ingested 20 items within the $2 \mathrm{~km}$ buffer around the moraine banks and 18 elsewhere. Bird \#27 ingested 63 and 24 items, respectively, in these habitats. The third bird visited the shelf north-east of Bird Island beyond the study area, where it ingested five items, but did not forage over any moraine banks (not illustrated). Birds \#22 and \#27 were

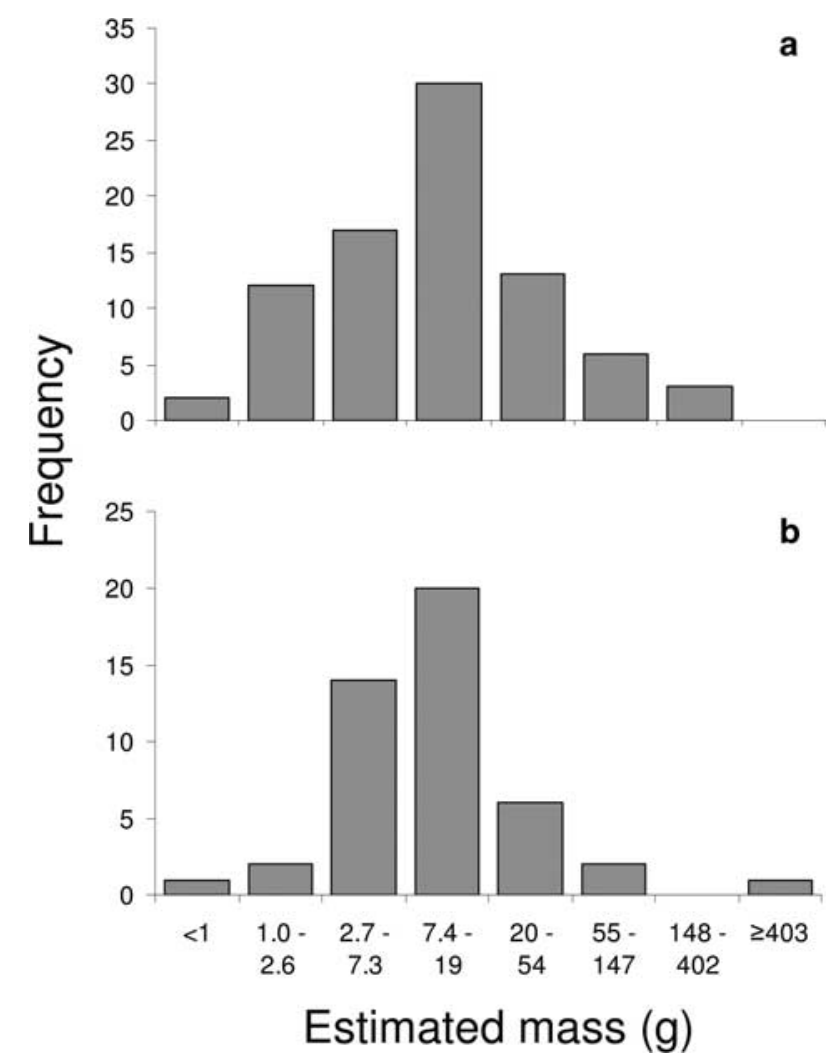

Fig. 7. Estimated mass of prey items ingested by two black-browed albatrosses (birds \#22 and \#27) from Bird Island, South Georgia caught a. within $2 \mathrm{~km}$ of moraine banks, and b. beyond $2 \mathrm{~km}$ from moraine banks. Note use of logarithmic size categories. tracked between 14 and 22 March. They are unlikely to have interacted with any fishing vessels during this period, as none were reported to be present in the study area (Fig. 5).

The average estimated mass of the144 individual prey items ingested in the study area was $19.7 \mathrm{~g}(95 \%$ CIs $0.3-68.5 \mathrm{~g}$, masses log-normally distributed, Anderson-Darling test $A=2.395, \quad P<0.001)$. The mean mass of prey items ingested by birds \#22 and \#27 within the $2 \mathrm{~km}$ buffer around the moraine banks did not differ significantly from those ingested elsewhere (Fig. 7, one-way ANOVA for each bird, $F_{1,36}=2.09, P=0.157 ; F_{1,85}=1.15, P=0.286$ ). Considering data from all birds monitored with STAUs, the majority of prey (56\% of individual items, $75 \%$ by mass) was ingested during daylight. Bird \#22 only visited the banks and $2 \mathrm{~km}$ buffer during the day and so all prey taken in this habitat was caught in daylight. Bird \#27, which visited the banks during both light and darkness, ingested $98 \%$ of prey items ( $78 \%$ by mass) in this habitat during daylight. Regurgitates collected from 20 instrumented birds after they returned from foraging indicated that they had fed primarily on krill, followed by fish and cephalopods (49, 40 and $11 \%$ of regurgitates by weight respectively). Of these birds, eight foraged primarily in the study area, only one of which regurgitated any cephalopod remains. Regurgitates from bird \#22 predominantly comprised unidentified fish remains ( $95 \%$ by mass) and a small amount of krill. Bird \#27 exclusively regurgitated krill.

\section{Discussion}

Our tracking data clearly indicate that while on foraging trips in the vicinity of South Georgia, breeding black-browed albatrosses spend more time in waters overlaying moraine banks than expected by chance. By combining data from highly accurate GPS loggers and hydrographic surveys, it was possible to relate the movements of individual wide-ranging marine predators to habitat at a finer scale than has hitherto been possible. Furthermore, although the sample size was low, the information on prey ingestion derived from stomach temperature loggers was invaluable for showing that blackbrowed albatrosses visiting waters overlaying moraine banks forage actively, in some cases in intensive bouts. Before exploring the reasons for the relationship between benthic habitat and albatross distribution, and its possible implications, we discuss the limitations of our study and some relevant inferences about prey in relation to habitat.

\section{Limitations of the study}

Firstly, given a lack of detailed benthic habitat data, we used a necessarily coarse habitat classification scheme (i.e. waters overlaying moraine banks, or not overlaying such banks). If the benthic habitats of the South Georgia shelf are mapped in more detail and our understanding of the mechanisms linking these to prey availability in superficial waters advances (Smith et al. 2006), less arbitrary, more 
biologically meaningful habitat distinctions should be possible (Aarts et al. 2008).

Secondly, we quantified habitat use within a relatively small area compared to the total area utilized by blackbrowed albatrosses foraging from South Georgia (cf. our Fig. 3 and fig. 1 in Phillips et al. 2004). Our models performed well for the shelf and slope region but poorly beyond this, where presence locations were sparse (Fig. 4). Previously we have shown that at the mega- to mesoscale, chick-rearing black-browed albatrosses prefer in ascending order oceanic, upper shelf slope, shelf break and neritic habitats (Wakefield et al. 2011). Birds from South Georgia travel as far away as the Antarctic Peninsula and the Patagonian shelf to access the latter types. In these areas the tendency to forage over moraine banks documented in the present study may be replaced by other sub-mesoscale habitat preferences. Therefore, data on seabed substrate throughout shelf waters accessible to this and other populations would be required to establish the generality of our findings. Similarly, the tendency for black-browed albatrosses from some populations to forage at the shelf break had the potential to confound our findings (Cherel et al. 2000, Wakefield et al. 2011). This is because terminal moraines from the Last Glacial Maximum also tend to occur at shelf margins (Syvitski 1991). However, the inclusion of depth, in addition to habitat type, in our models effectively captured variability in spatial usage due to proximity to the shelf break (Fig. 4). Furthermore, visual examination of the GPS, STAU and habitat data shows a remarkable congruence between the tracks of the birds and the distribution of the banks within the shelf break zone (Figs $3 \& 6$ ).

Finally, we analysed albatross habitat use in the vicinity of South Georgia. However, as noted above, many of the tracked birds flew rapidly through the study area, commuting to more distant foraging sites. Excluding these birds from our analysis would have allowed us to focus only on the behaviour of the birds that spent the majority of their time in the study area. However, it would have been inappropriate given that both black-browed albatrosses and their close relatives greyheaded albatrosses Thalassarche chrysostoma (Forster, 1785) sometimes forage (albeit to a limited extent) during the commuting stages of provisioning trips (Catry et al. 2004, Wakefield, unpublished data). Indeed, we noted that some of the longer-ranging birds in this study also visited the moraine banks. Hence, habitat selection may have been made even while the birds were primarily concerned with commuting.

\section{Type of prey captured over the banks}

The diet of the birds observed during the study was typical of that of chick-rearing black-browed albatrosses from South Georgia during years of high krill abundance, being dominated by krill and fish (Reid et al. 1996). Cephalopods, the other major prey taxon taken by this population, were extremely rare in the diet of the birds that foraged predominantly in local neritic waters. In a previous studies, fish caught by black-browed albatrosses had estimated masses ranging from $0.5-2012 \mathrm{~g}$, with the vast majority weighing $>50 \mathrm{~g}$ (Reid et al. 1996, Cherel et al. 2000), whereas the mass of individual krill fed to chicks at Bird Island typically ranges from 1-22 g (Croxall et al. 1997). Comparing these figures to the distribution of prey masses estimated using the STAU data (Fig. 7) it seems that the prey captured by birds \#22 and \#27 in waters overlaying moraine banks probably consisted of krill and fish in approximately equal proportions. A closer examination of the PDER events recorded both on and off the moraine banks shows that in some instances many small prey items were ingested in quick succession. We interpret this as krill or other small shoaling prey being caught rapidly, one by one.

\section{Do albatrosses use the banks because of attraction to trawlers?}

It is highly unlikely that black-browed albatrosses spend more time foraging over moraine banks than over surrounding habitats by chance, so some explanation for why this occurs is needed. One possibility is that birds are attracted to trawlers, which either target the banks or associated shoals of mackerel icefish. It is well known that black-browed albatrosses scavenge from trawlers (and as a consequence are frequently killed by trawl warps) (Sullivan et al. 2006). However, such attraction to trawlers could at best only account for a small proportion of the birds' association with moraine banks during our study because this occurred when fishing boats were both present and absent. For example, during our study bank 5 was visited by two tracked albatrosses but no fishing boats (Figs $2 \& 3$ ). Furthermore, recent research in the Falklands indicates a great deal of individual variability in associations between blackbrowed albatrosses and fishing vessels, with the majority of birds in a given population not targeting vessels even if they are easily within foraging range (Granadeiro et al. 2011).

However, we caution firstly, that our analysis relied on the accuracy of reported set and haul data, which in the past have contained errors (Kock 2001) and secondly, that we had no information on the movements of trawlers while not engaged in fishing. As such, it is possible that birds were attracted to fishing boats not actively trawling but perhaps engaged in prospecting for fish on the banks. However, this is unlikely firstly, because black-browed albatrosses are primarily attracted to working (and especially actively discarding) trawlers (Sullivan et al. 2006), and secondly because fishing boats were entirely absent from the study area for the majority of the study's duration (Fig. 5).

\section{Do albatrosses use the banks because of upward benthic-pelagic coupling?}

Most documented instances of benthic-pelagic coupling usually involve a downwards transfer of energy through the 
water column, such that production at higher trophic levels in benthic ecosystems is regulated by primary production in epipelagic waters (Graf 1992). However, processes occurring at or near the seabed may also affect biomass in epipelagic waters, giving rise to upward benthic-pelagic coupling (Smith et al. 2006). As such, variability in prey abundance in surface waters may be mechanistically linked to the patchiness of benthic habitats, explaining the observed distribution of surface-feeding black-browed albatrosses. What might these links be? We discuss three, not necessarily mutually exclusive, hypotheses.

The first process by which the banks could give rise to higher prey availability in surface waters is through the upward export of enhanced benthic production. Barnes (2008) described how substrates comprised of boulders, presumably themselves glacial moraines, on shelf and shelf slopes of the Shag Rocks, to the west of South Georgia, sustained a much richer fauna than surrounding habitats. On the boulders a cryptofauna of filter feeders that exploit the interstitial spaces characteristic of such large grained sediments predominates. In other shelf seas demersal fish are known to be more abundant in such topographically complex, mixed glacial sediment habitats (Todd \& Kostylev 2011). It is possible therefore, that black-browed albatrosses are attracted to the banks in order to predate demersal fish, which frequently appear in their diet (Reid et al. 1996, Cherel et al. 2000). Although it is not clear how they would access such prey (Cherel et al. 2000), some fish taken by albatrosses during foraging trips from South Georgia feed both benthically and near the surface (Collins et al. 2008). However, this would offer a rather incomplete explanation because it is probable that a large proportion of the prey caught by black-browed albatrosses on the banks was krill rather than fish.

A second mechanism could potentially enhance the availability of krill (and also therefore planktivorous fish) in surface waters overlaying the banks. Although krill primarily feed pelagically, they have also been observed grazing photodetritus (the remains of phytoplankton) on the seabed at depths well in excess of that of the South Georgia shelf (Gutt \& Siegel 1994). Gutt (2000) pointed out that krill swarms migrating to the surface, which they are able to do rapidly (Clarke \& Tyler 2008), can transfer energy from the seabed to surface-feeding predators. It is possible that as currents pass over the moraine banks, eddies cause photodetritus to accumulate in their lee or in the interstitial spaces between their component cobbles and boulders. This would provide a more profitable grazing habitat for krill swarms than the surrounding seafloor. Krill would themselves become available in surface waters due to habitual diel vertical migrations (Everson 1983). As yet, little is known about the frequency of benthic feeding in krill so this is a very speculative hypothesis.

Finally, the banks may cause local enhancement of phytoplankton growth in the epipelagic zone. Currents on the South Georgia shelf have velocities in the order of
$1-15 \mathrm{~cm} \mathrm{~s}^{-1}$ (Atkinson et al. 2001). The turbulence these create as they pass over the banks, some of which rise to over $100 \mathrm{~m}$ above the seabed, could conceivably enhance vertical mixing, re-supplying limiting nutrients to the photic zone in a similar process to those occurring around oceanic seamounts (Lueck \& Mudge 1997). Although South Georgia shelf waters are not thought to be significantly nutrient limited (Atkinson et al. 2001), this process could become important at the outer shelf, where the influence of nutrient poor oceanic waters is most apparent. Indeed, it would be facilitated by the weak degree of stratification of these waters (Sedwick et al. 2000). Similarly, the dynamics of the South Georgia shelf break front, a feature that also gives rise to localized nutrient upwelling, are tied to small-scale bathymetry (Brandon et al. 1999). Increased stocks of phytoplankton due to such nutrient re-supply would sustain higher levels of secondary production, principally of Antarctic krill, a major component in the diet of both black-browed albatrosses and mackerel icefish (Kock et al. 1994, Croxall et al. 1997). Furthermore, turbulence caused by the banks could result in the retention of phytoplankton and zooplankton in their vicinity (Barth et al. 2005).

\section{Wider implications}

Links between the spatial usage of surface-feeding, pelagic seabirds and the distribution of benthic habitats are perhaps counter intuitive but deserve wider investigation. Yet, to our knowledge, this is the first time a study such as ours has been carried out. In part this is because tracking devices and remote sensing (now the predominant tools used to study pelagic seabird habitat use) were not hitherto accurate enough to examine sub-mesoscale habitat interactions (Wakefield et al. 2009). However, GPS tracking now allows individual seabird movements to be recorded to an accuracy of $c . \pm 5 \mathrm{~m}$, and equally accurate acoustic mapping of seabed habitats is now becoming available. In this context, it is notable that moraine banks are a common feature of continental shelves (Syvitski 1991), with wellknown examples including the Grand Banks of Canada and the Dogger Bank of the North Sea. Furthermore, the prey of many surface-feeding pelagic seabirds, especially those that routinely forage in neritic waters have well-known preferences for habitats characterized by particular seabed sediments (e.g. Frederiksen et al. 2005).

A useful way of contextualising the results of fine-scale studies of pelagic seabird habitat use such as ours is within the conceptual framework of hierarchical patches (Fauchald et al. 2000). For example, as we have previously shown, at the meso- to macroscale chick-rearing black-browed albatrosses from South Georgia prefer to forage in neritic and shelf break waters (Wakefield et al. 2011). Our present findings imply that within these neritic habitat patches they also show preference at the sub-mesoscale, in this case for waters overlaying a particular benthic habitat. This supports the view that at large 
to medium spatial scales the distribution of predators reflects that of prey (Fauchald et al. 2000). Indeed, black-browed albatrosses' putative mesoscale preference for shelf break and upper slope habitats (Cherel et al. 2002, Wakefield et al. 2011) may in fact arise due to a sub-mesoscale preference for moraine substrates, which predominantly occur at shelf edges (Syvitski 1991). Hence, an understanding of such fine-scale habitat use may be informative not only about the ecology of seabirds but also about processes of benthic-pelagic coupling, which are clearly deserving of further study.

\section{Acknowledgements}

The authors gratefully acknowledge generous financial support provided for the fieldwork element of this study by the Antarctic Science Bursary and the Russell Trust, as well as logistical support provided in kind by the UK Antarctic Funding Initiative Collaborative Gearing Scheme. This study was partly carried out while the first author was in receipt of a UK Natural Environment Research Council CASE studentship (NER/S/A/2005/13648). We thank Peter Fretwell for providing a shapefile depicting the extent of moraine banks around South Georgia and Dr Jose Xavier for identifying prey samples. We thank the Government of South Georgia and South Sandwich Islands for permission to use fishery effort data. We are very grateful to Ewan Edwards, Derren Fox, Fabrice le Bouard, Donald Malone, Chris Martin, Felice Prospero-Porti, Robin Snape and John Withers for assisting with fieldwork at Bird Island and to Prof John Croxall for supporting long-term studies there. We thank two anonymous referees for helpful comments on an earlier draft of this manuscript.

\section{References}

Aarts, G., MacKenzie, M., McConnell, B., Fedak, M. \& Matthiopoulos, J. 2008. Estimating space-use and habitat preference from wildlife telemetry data. Ecography, 31, 140-160.

Atkinson, A., Whitehouse, M.J., Priddle, J., Cripps, G.C., Ward, P. \& Brandon, M.A. 2001. South Georgia, Antarctica: a productive, cold water, pelagic ecosystem. Marine Ecology Progress Series, 216, 279-308.

BARNES, D.K.A. 2008. A benthic richness hotspot in the Southern Ocean: slope and shelf cryptic benthos of Shag Rocks. Antarctic Science, 20, 263-270.

Barth, J.A., Pierce, S.D. \& Castelao, R.M. 2005. Time-dependent, winddriven flow over a shallow midshelf submarine bank. Journal of Geophysical Research, 10.1029/2004JC002761.

Brandon, M.A., Murphy, E.J., Whitehouse, M.J., Trathan, P.N., Murray, A.W.A., Bone, D.G. \& PriddLe, J. 1999. The shelf break front to the east of the sub-Antarctic island of South Georgia. Continental Shelf Research, 19, 799-819.

Catry, P., Phillips, R.A., Phalan, B., Silk, J.R.D. \& Croxall, J.P. 2004. Foraging strategies of grey-headed albatrosses Thalassarche chrysostoma: integration of movements, activity and feeding events. Marine Ecology Progress Series, 280, 261-273.

CCAMLR. 2009. Statistical Bulletin. Hobart, TAS: CCAMLR, 241 pp.

Cherel, Y. \& Klages, N.T.W. 1998. A review of the food of albatrosses. In Robertson, G. \& Gales, R., eds. Albatross biology and conservation. Chipping Norton: Surrey Beatty \& Sons, 113-136.
Cherel, Y., Weimerskirch, H. \& Trouve, C. 2000. Food and feeding ecology of the neritic-slope forager black-browed albatross and its relationships with commercial fisheries in Kerguelen waters. Marine Ecology Progress Series, 207, 183-199.

Cherel, Y., Weimerskirch, H. \& Trouve, C. 2002. Dietary evidence for spatial foraging segregation in sympatric albatrosses (Diomedea spp.) rearing chicks at Iles Nuageuses, Kerguelen. Marine Biology, 141, 1117-1129.

Clarke, A. \& Tyler, P.A. 2008. Adult Antarctic krill feeding at abyssal depths. Current Biology, 18, 282-285.

Collins, M.A., Shreeve, R.S., Fielding, S. \& Thurston, M.H. 2008. Distribution, growth, diet and foraging behaviour of the yellow-fin notothen Patagonotothen guntheri (Norman) on the Shag Rocks shelf (Southern Ocean). Journal of Fish Biology, 72, 271-286.

Croxall, J.P., Prince, P.A. \& Reid, K. 1997. Dietary segregation of krilleating South Georgia seabirds. Journal of Zoology, 242, 531-556.

EVERSON, I. 1983. Variations in vertical distribution and density of krill swarms in the vicinity of South Georgia. Memoirs of the National Institute of Polar Research, Special Issue, No. 27, 84-92.

Fauchald, P., Erikstad, K.E. \& Skarsfjord, H. 2000. Scale-dependent predator-prey interactions: the hierarchical spatial distribution of seabirds and prey. Ecology, 81, 773-783.

Frederiksen, M., Wright, P.J., Harris, M.P., Mavor, R.A., Heubeck, M. \& Wanless, S. 2005. Regional patterns of kittiwake Rissa tridactyla breeding success are related to variability in sandeel recruitment. Marine Ecology Progress Series, 300, 201-211.

Fretwell, P.T., Tate, A.J., Deen, T.J. \& Belchier, M. 2009. Compilation of a new bathymetric dataset of South Georgia. Antarctic Science, 21, 171-174.

GrAF, G. 1992. Benthic-pelagic coupling - a benthic view. Oceanography and Marine Biology, 30, 149-190.

Graham, A.G.C., Fretwell, P.T., Larter, R.D., Hodgson, D.A., Wilson, C.K., TATE, A.J. \& MoRRIs, P. 2008. A new bathymetric compilation highlighting extensive paleo-ice sheet drainage on the continental shelf, South Georgia, sub-Antarctica. Geochemistry Geophysics Geosystems, 9, 21.

Granadeiro, J.P., Phillips, R.A., Brickle, P. \& Catry, P. 2011. Albatrosses following fishing vessels: how badly hooked are they on an easy meal? Plos One, 6, e17467.

Greenstreet, S.P.R., Spence, F.B., Shanks, A.M. \& McMillan, J.A. 1999. Fishing effects in northeast Atlantic shelf seas: patterns in fishing effort, diversity and community structure. II. Trends in fishing effort in the North Sea by UK registered vessels landing in Scotland. Fisheries Research, 40, 107-124.

GuTT, J. 2000. Some "driving forces" structuring communities of the sublittoral Antarctic macrobenthos. Antarctic Science, 12, 297-313.

Gutt, J. \& Siegel, V. 1994. Benthopelagic aggregations of krill (Euphausia superba) on the deeper shelf of the Weddell Sea (Antarctic). Deep Sea Research I, 41, 169-178.

JoHNSON, D.H. 1980. The comparison of usage and availability measurements for evaluating resource preference. Ecology, 61, 65-71.

Kock, K.H. 2001. The direct influence of fishing and fishery-related activities on non-target species in the Southern Ocean with particular emphasis on longline fishing and its impact on albatrosses and petrels - a review. Reviews in Fish Biology and Fisheries, 11, 31-56.

Kock, K.H., Wilhelms, S., Everson, I. \& Groger, J. 1994. Variations in the diet composition and feeding intensity of mackerel icefish Champsocephalus gunnari at South Georgia (Antarctic). Marine Ecology Progress Series, 108, 43-57.

Lueck, R.G. \& MudGe, T.D. 1997. Topographically induced mixing around a shallow seamount. Science, 276, 1831-1833.

Phillips, R.A., Silk, J.R.D., Croxall, J.P., Afanasyev, V. \& Bennett, V.J. 2005. Summer distribution and migration of nonbreeding albatrosses: individual consistencies and implications for conservation. Ecology, 86, 2386-2396.

Phillips, R.A., Silk, J.R.D., Phalan, B., Catry, P. \& Croxall, J.P. 2004. Seasonal sexual segregation in two Thalassarche albatross species: competitive exclusion, reproductive role specialization or foraging niche divergence? Proceedings of the Royal Society London, B271, 1283-1291. 
Pinaud, D. \& Weimerskirch, H. 2007. At-sea distribution and scaledependent foraging behaviour of petrels and albatrosses: a comparative study. Journal of Animal Ecology, 76, 9-19.

Prince, P.A., Huin, N. \& Weimerskirch, H. 1994. Diving depths of albatrosses. Antarctic Science, 6, 353-354.

Putz, K., Wilson, R.P., Charrassin, J.B., Raclot, T., Lage, J., Le Maho, Y., Kierspel, M.A.M., Culik, B.M. \& Adelung, D. 1998. Foraging strategy of king penguins (Aptenodytes patagonicus) during summer at the Iles Crozet. Ecology, 79, 1905-1921.

Reid, K., Croxall, J.P. \& Prince, P.A. 1996. The fish diet of black-browed albatross Diomedea melanophris and grey-headed albatross $D$. chrysostoma at South Georgia. Polar Biology, 16, 469-477.

Sedwick, P.N., DiTullio, G.R. \& MAckey, D.J. 2000. Iron and manganese in the Ross Sea, Antarctica: seasonal iron limitation in Antarctic shelf waters. Journal of Geophysical Research, 105, 11 321-11336.

Smith, C.R., Mincks, S. \& DeMaster, D.J. 2006. A synthesis of benthopelagic coupling on the Antarctic shelf: food banks, ecosystem inertia and global climate change. Deep Sea Research II, 53, 875-894.

Sullivan, B.J., Reid, T.A. \& Bugoni, L. 2006. Seabird mortality on factory trawlers in the Falkland Islands and beyond. Biological Conservation, 131, 495-504.
SyviTSKi, J.P.M. 1991. Towards an understanding of sediment deposition on glaciated continental shelves. Continental Shelf Research, 11, 897-937.

Todd, B.J. \& Kostylev, V.E. 2011. Surficial geology and benthic habitat of the German Bank seabed, Scotian Shelf, Canada. Continental Shelf Research, 31, S54-S68.

Wakefield, E.D., Phillips, R.A. \& Matthiopoulos, J. 2009. Quantifying the habitat use and preference of pelagic seabirds using individual movement data: a review. Marine Ecology Progress Series, 391, 165-182.

Wakefield, E.D., Phillips, R.A., Trathan, P., Arata, J., Gales, R., Huin, N., Robertson, G., Waugh, S., Weimerskirch, H. \& Matthiopoulos, J. 2011. Accessibility, habitat preference and conspecific competition limit the global distribution of breeding albatrosses. Ecological Monographs, 81, 141-167.

Waugh, S.M., Weimerskirch, H., Cherel, Y. \& Prince, P.A. 2000. Contrasting strategies of provisioning and chick growth in two sympatrically breeding albatrosses at Campbell Island, New Zealand. Condor, 102, 804-813.

Wilson, R.P., Putz, K., Gremillet, D., Culik, B.M., Kierspel, M., Regel, J., Bost, C.A., Lage, J. \& Cooper, J. 1995. Reliability of stomach temperature-changes in determining feeding characteristics of seabirds. Journal of Experimental Biology, 198, 1115-1135. 